DOI 10.18551/rjoas.2020-08.15

\title{
IDENTIFICATION OF ACTORS, FACTORS, RESTRUCTURING OPTIONS, AND IMPLEMENTATION STRATEGIES FOR IMPROVING PERFORMANCE AND GROWTH OF BUMD OF FOOD SECTOR IN JAKARTA
}

\author{
Siahaan Henry M.P.* \\ Business School, IPB University, Indonesia \\ Priyarsono Dominicus Savio \\ Department of Economics, Faculty of Economics and Management, IPB University, \\ Indonesia \\ Rifin Amzul \\ Department of Agribusiness, Faculty of Economics and Management, IPB University, \\ Indonesia \\ Arifin Bustanul \\ Department of Agricultural Economics/Agribusiness, University of Lampung, Indonesia \\ *E-mail: henrympsiahaan@gmail.com
}

\begin{abstract}
The market share control of BUMD in the food sector in Jakarta is between 2-8 percent. This condition has been unable to fulfill the target set by the Provincial Government and has not operated effectively as a regional parastatal. Therefore, efforts are being made through organic strategy to achieve a target of 30 percent, although it has been difficult. Meanwhile, there is a great chance of achieving this target because food demand continues to increase every year due to population growth. When the performance and growth of a company are no longer able to develop with classic or organic strategy, then inorganic growth is another alternative that can be taken. Therefore, this research aimed to identify the actors, factors, and the most appropriate strategy alternatives to improve the performance and growth of BUMD, and how to implement them. Quantitative methods were used, which based on questionnaires from 5 experts who understand the characteristics and business processes of 3 BUMDs in the food sector. Furthermore, data were analyzed by AHP and triangulation methods to formulate implementation strategies using BMC. The results showed that at the level of Actor, Factor, and Strategy alternative, the most important are BUMD management, GCG, and holding company respectively. The recommended classification is a management holding company, which can control and monitor the business decision making of the subsidiary. However, the biggest challenge is GCG that is less optimal, disparities in human resources, weak competitive advantage, and political intervention.
\end{abstract}

\section{KEY WORDS}

Corporate restructure, regionally-owned holding company, management, strategy.

The high demand for food each year in Jakarta due to increasing population is a great opportunity for rice and cow or buffalo meat business. Based on the average rice consumption of $114 \mathrm{~kg} / \mathrm{year}$ in Indonesia (Central Bureau of Statistics, 2015), and a projected population of 10.504 million in Jakarta (Central Bureau of Statistics, 2020), the need for this commodity is $1,197,456$ tons. Furthermore, cow and buffalo meat consumption is $2.66 \mathrm{~kg} /$ capita/year (Deptan 2020), therefore at least 29,411 tonnes are required by 2020. Hence, to seize the market share, it is necessary to formulate the right strategy.

Unfortunately, Regional-Owned Enterprises (BUMDs) are generally concluded to be unhealthy. These are because of unprofessional management, commissioners who have personal relationships with BUMD leaders, the provincial government and the Regional 
People's Representative Assembly (DPRD) who are not professional, as well as clients that are not critical of performance (Asaari 2000). Therefore, new efforts are needed, and the Provincial Government needs to conduct a thorough evaluation. Moreover, the impact of the Covid-19 pandemic has caused a global recession (World Bank 2020) and transformed new consumer behavior (Kohli et al. 2020). This impact also hits the economy of Jakarta, making the Regional Budget (APBD) to decrease significantly in a relatively long time. Hence, BUMDs need to adapt immediately.

Therefore, this research aimed to identify actors, factors, and the most appropriate strategy alternatives for institutional restructuring that affect the performance and growth of BUMD in the food sector. It also aimed to identify how the strategy alternatives are selected based on the first objective.

\section{LITERATURE REVIEW}

According to Thompson and Martin (2005), there are 3 approaches in corporate growth strategy. The first is limited or internal growth, which is carried out through market penetration and product development all of which depend and are related to company innovation, as well as a combination of these options. Meanwhile, limited growth is basically organic (classic strategy). The second is the company's substantive growth implemented in corporate restructuring. Also, Thompson and Martin stated that substantive growth is carried out with horizontal and vertical integration, as well as related concentric, and conglomerate diversification. This is often implemented through acquisitions, mergers or joint ventures rather than organic growth. Meanwhile, according to Baye and Prince (2013), growth strategy alternatives are carried out through vertical and horizontal integration, as well as conglomerate mergers. Thompson et al., also stated that growth is inorganic. The third approach is austerity, which is carried out to revitalize the company, in order to improve competitiveness and efficiency by making turnarounds and divestments.

Company restructuring is an alternative method to overcome poor performance, pursue new strategic opportunities, and gain credibility with the capital market. This is achieved by improving financial performance, recognizing and allocating financial losses, exploiting new strategic opportunities and gaining credibility with capital markets, restructuring institutional financial claims and corporations. Furthermore, it involves restructuring the operations of financial institutions and corporations with various components, such as shareholders, creditors, employees, suppliers, customers, and government (Pomerleano and Shaw 2005, Gilson 2001, Krishnamurti and Vishwanath 2008).

This restructuring process is not only conducted in companies experiencing difficulties, but also for those that want to improve their performance (Vance 2009). Corporate restructuring is commonly carried out in a business due to a shift in strategy with various considerations, such as the need to make the company healthy, preventing greater losses, bankruptcy, enlarging the scale, controlling or demanding the market, and penetrating the export market. It also includes the need to control the resources and distribution channels, sharpening business focus, mastering IT and IPR, fulfilling the latest regulatory requirements, having new opportunities, increasing access to capital, and others (Djohanputro 2004).

\section{METHODS OF RESEARCH}

This study was conducted for 3 months from March-May 2020. Furthermore, the objects were 3 BUMDs in the food sector in Jakarta, namely Perumda Pasar, PD Dharma, and PT Food Station Tjipinang Jaya. The quantitative descriptive method (Creswell 2014) used questionnaire from 5 respondents, who are experts that understand the characteristics and business processes of the three BUMDs. They also have backgrounds from elements of the Provincial Government, Regional People's Representative Assembly, state development supervisory agencies, and practitioner or observer. 


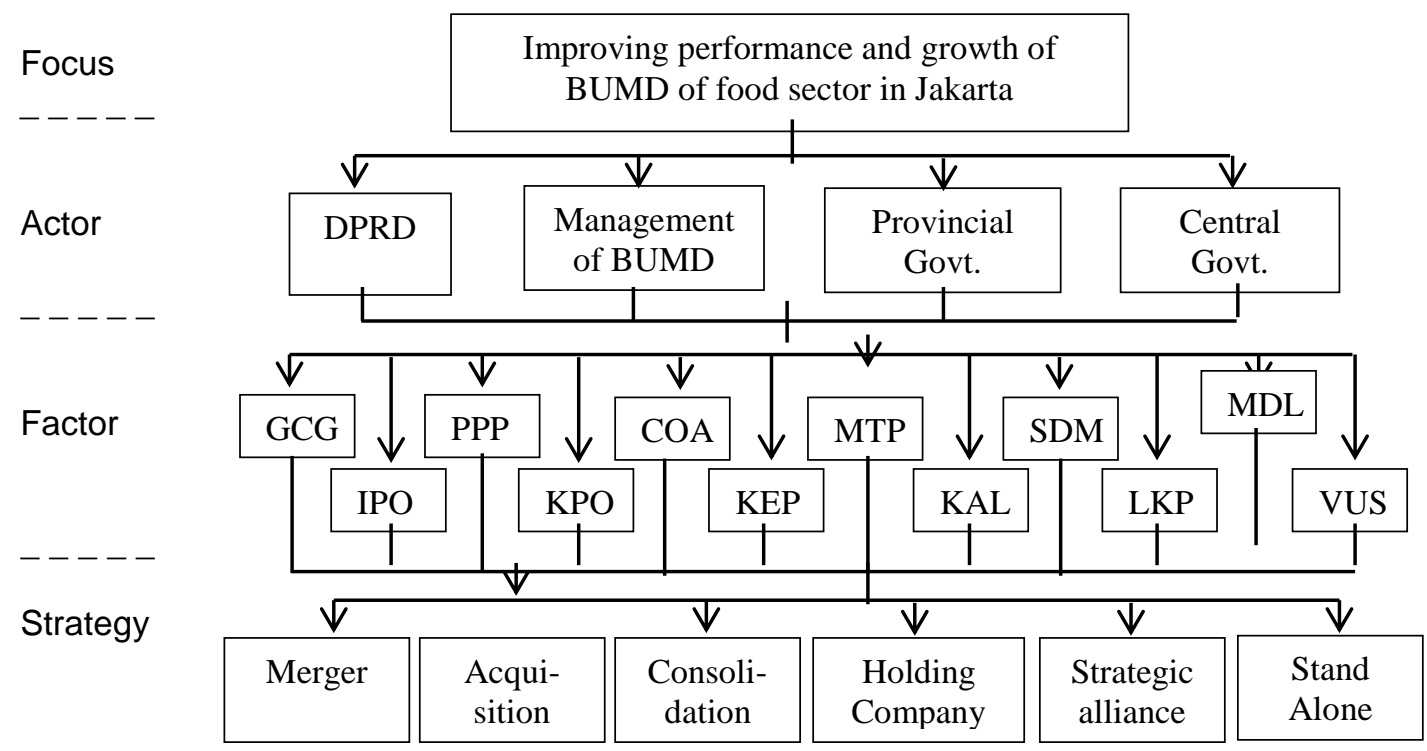

Figure 1 - AHP Hierarchical Structure Model

In the first research objective, data were analyzed using the Analytical Hierarchy Process (AHP) formulated by Saaty (1993). In interviews with the respondents, a pairwise comparison method was used to determine the weight of each indicator. Furthermore, the weight determination was carried out by submitting a questionnaire that is open to the respondents. For pairwise comparisons, the Expert Choice software version 11.0 was used. Meanwhile, in the AHP hierarchical structure model (Figure 1), the first level is Actor which consists of 4 aspects, namely DPRD, BUMD Management, Provincial and Central Government. The second level is a factor that consists of 12 aspects, which are Corporate governance/GCG, Political intervention/IPO, role of the central government/PPP, Company capability/KPO, Competitive advantage/COA, Company control/KEP, Multi-purpose/MTP, Alliance capability/KAL, Human resource capacity/SDM, Environment and market conditions/LKP, Capital structure/MDL, and Business volume/VUS. Meanwhile, the third level is a strategy alternative which consists of 6 things, which are Merger, Acquisition, Consolidation, Holding Company, Strategic Alliance, and Stand Alone.

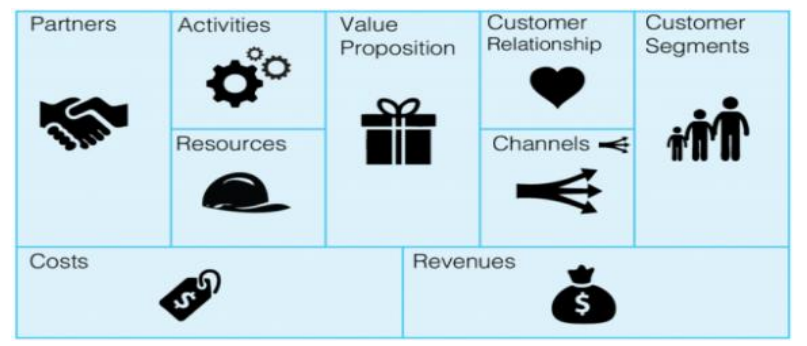

Figure 2 - The nine elements of BMC (Source: Osterwalder and Pigneur 2010)

The second objective is to formulate an implementation strategy of the highest choice for the Alternative level of AHP through the modified BMC method (Figure 2). BMC is a method of formulating a framework that discusses business models through images and designs. This is done by condensing several aspects into one complete strategy using the visualization of a painting canvas (Osterwalder and Pigneur 2010).

\section{RESULTS AND DISCUSSION}

Actor level results. Based on the results of processed data using AHP for priority criteria of actors from the expert perspective, the largest geometric mean (GMk) was 0.483 in 
the BUMD Management category. This means the management is the most important actor, and it plays a role in improving the performance and growth in the food sector. These results are in accordance with strategic theory which states that company management is the party that understands the position of the organization, make choices for the future, and turns plan into action (Johnson et al. 2005). Furthermore, management is responsible for corporate strategy formulation, implementation, and evaluation (David 2011). The second place is the Provincial Government with a geometric mean value of 0.312 . Meanwhile, the third priority actor is the Central Government with a geometric mean value of 0.109 , followed by DPRD with a value of 0.097 .

Factor level results. Based on the results of processed data, the largest geometric mean (GMk) was 0.183 in Good Corporate Governance (GCG). This means good governance is the most important and main factor in improving the performance and growth of BUMD. This is in accordance with Holida \& Suryadi (2012) which stated that the corporate governance affects company performance. Ferial, Suhadak, Handayani (2016) showed that BUMD has a significant and positive effect on the value of state companies. Therefore, the management needs to formulate and implement GCG Guidelines including Code of Conduct as a direction in Governor Regulation No. 96 of 2004 on the Implementation of GCG Practices. Also, the Provincial Government needs to closely monitor and evaluate the implementation.

The second important factor is related to HR capacity with a geometric mean value of 0.153. It is also important for the human resource capacity factor, especially in the information technology era where they are required to work more responsively. The HR capacity includes knowledge, skills, behavior, and work ethics from the lowest to the highest level employees, including the company's commissioners or supervisory board. Furthermore, bureaucratic work with a lack of entrepreneurial traits at the management level causes slow response to market needs and opportunities. Also, BUMD needs to be managed in a more professional manner and kept away from bureaucratic interference. The Minister of Home Affairs Regulation No. 37 of 2018 on the appointment and dismissal of the supervisory board members of BUMD, where regional officials are given the opportunity to become commissioners needs to be reviewed.

The third and fourth factors according to experts are related to the company's competitive advantage and capability with geometric mean values of 0.112 and 0.103 respectively. These two factors are the most important after governance and human resource capacity. Furthermore, the sequence of factors for increasing performance and growth is not too different, starting from the alliance ability/KAL (0.077), company control/ KEP (0.074), capital structure/MDL (0.066), Multi-purpose/MTP (0.058), business volume/VUS (0.057), Market environment and condition/LKP (0.047), political intervention/IPO (0.043) and the role of the central government/PPP $(0.028)$.

Strategy Alternative level results. Based on the processed data, the largest geometric mean (GMk) was 0.256 for the Holding Company strategy. This showed that holding company is the most important alternative in the model of improving the performance and growth of BUMD. Also, the establishment of a holding company is believed to be a strategic and effective step to accelerate the achievement of performance and growth targets. Therefore, the Provincial Government and DPRD can learn from the success stories and failures of establishing holding companies in Singapore, Malaysia, China and Indonesia. Also, institutional restructuring is the main stage which is then followed by the next steps consistently (Pranoto 2017, Bhatt 2016, Hassard et al. 2010). Wong (2004) stated that the political commitment to be implemented is not enough, hence a professional supervision system that includes checks and balances as part of good corporate governance is needed. Therefore, the Government needs to formulate these efforts more comprehensively with concrete steps towards the formation of a holding company.

The second alternative sequence is a strategic alliance with a GMK of 0.213 , while the third according to experts is a consolidation method with a GMK of 0.192 . This means the strategic alliance and consolidation methods are the most important alternatives after the Holding Company. The fourth strategy alternative sequence according to experts is the 
merger method with a GMK of 0.150 . Meanwhile, the fifth and sixth alternatives are the acquisition and methods with weight values of 0.120 and 0.069 respectively.

The choice at the highest alternative level according to 5 experts is the Holding Company, therefore the canvas model business formula description is based on this choice, as shown in Figure 3.

\begin{tabular}{|c|c|c|c|c|c|}
\hline $\begin{array}{l}\text { Key } \\
\text { Partnership }\end{array}$ & $\begin{array}{l}\text { Key } \\
\text { Activities }\end{array}$ & \multicolumn{2}{|c|}{$\begin{array}{l}\text { Value } \\
\text { Proposition } \\
\text { Supply side : } \\
\text { (1) Better } \\
\text { (2) Accessibility }\end{array}$} & $\begin{array}{l}\text { Customer } \\
\text { Relationship }\end{array}$ & $\begin{array}{l}\text { Customer } \\
\text { Segment }\end{array}$ \\
\hline \multirow[t]{3}{*}{$\begin{array}{l}\text { (1) Jakarta } \\
\text { Provincial } \\
\text { Govern- } \\
\text { ment } \\
\text { (2) Jakarta } \\
\text { DPRD }\end{array}$} & $\begin{array}{l}\text { (1) Production } \\
\text { operations } \\
\text { (2) Marketing } \\
\text { (3) Customer } \\
\text { services } \\
\text { (4) IT } \\
\text { (5) Arrangement } \\
\text { of assets }\end{array}$ & \multirow{3}{*}{\multicolumn{2}{|c|}{$\begin{array}{l}\text { Demand side: } \\
\text { (1) Accessibility } \\
\text { (2) Convenience } \\
\text { (3) Availability } \\
\text { of supply }\end{array}$}} & $\begin{array}{l}\text { (1) Supply side: } \\
\text { personal assistance, } \\
\text { dedicated personal } \\
\text { assistance, } \\
\text { automated service } \\
\text { (2) Demand side: } \\
\text { newsletter or media } \\
\text { social. } \\
\text { (3) Build customer } \\
\text { data } \\
\text { collaboratively }\end{array}$ & \multirow[t]{3}{*}{$\begin{array}{l}\text { (1) upper class } \\
\text { society } \\
\text { (2) middle class } \\
\text { society } \\
\text { (3) lower class } \\
\text { society }\end{array}$} \\
\hline & $\begin{array}{l}\text { Key } \\
\text { Resources (팔 }\end{array}$ & & & Channels & \\
\hline & $\begin{array}{l}\text { (1) Physical } \\
\text { facilities } \\
\text { (2) HR } \\
\text { (3) Financial } \\
\text { (4) Intellectual }\end{array}$ & & & $\begin{array}{l}\text { (1) Direct channel } \\
\text { (2) Indirect channel } \\
\text { (3) Social media }\end{array}$ & \\
\hline \multicolumn{2}{|l|}{ Obstacles } & ossixars & \multicolumn{2}{|c|}{ Benefits } & \\
\hline \multicolumn{3}{|c|}{$\begin{array}{l}\text { (1) Not optimal corporate governance } \\
\text { (2) Disparities in HR } \\
\text { (3) Capital and finances of each BUMD } \\
\text { (4) Political intervention }\end{array}$} & \multicolumn{3}{|c|}{$\begin{array}{l}\text { (1) More efficient operational costs } \\
\text { (2) Ease of access to sources of capital } \\
\text { (3) The assets and networks of the three large BUMDs } \\
\text { (4) Regional capital participation (PMD) support from } \\
\text { the Jakarta Provincial Government } \\
\text { (5) The increase of service to society }\end{array}$} \\
\hline
\end{tabular}

Figure 3 - Development of BMC for the BUMD holding company in food sector

Customer Segment. This segment describes the targeted customer groups and those that needs to be maintained. Based on the supply and demand, supply-side customers are groups of goods and services suppliers, tenants of buildings or kiosks and vendors or traders with the three BUMDs. From the demand side, customers are buyers of goods and services provided directly by suppliers or third-party. This means the customers of the three BUMDs are multi-sided markets.

By using socio-economic stratification based on income or wealth, buyers are divided into 3 groups, which are people in the upper, middle, and lower economic class.

Based on data from Perumda Pasar Jaya, there are two million buyers visiting traditional markets every day (http://pasariaya.co.id/about/detail/Tentang-Kami). Meanwhile, PT Food Station Tjipinang and PD Dharma Jaya facilitate the provision and distribution of rice, meat, milk, and others for certain groups of people (low-income economies) according to the Jakarta Governor Regulation No. 6 of 2018 on the Provision and Distribution of Food at Low Prices for Certain Communities.

Value Proposition. The holding company in food sector is expected to effectively create synergy over all the resources owned by the three BUMDs including capital, human resources, movable and immovable assets, as well as a network that has been built. Therefore, competition will be more balanced, effective, and efficient in making decisions within the company. Hence, the value offered by the company to customers is a more 
effective and efficient bureaucracy, better performance, as well as better accessibility and comfort.

A food holding company creates customer interest with a specific segment through a strategy of novelty value creation, performance, customization, getting the job done, design, brand, price, cost reduction, risk reduction, accessibility and comfort. Meanwhile, the benefits obtained by the customers can be quantitative in the form of price, speed, and service. Furthermore, it can be qualitative in the form of design and customer experience (Osterwelder and Pigneur 2010).

Table 1 - Value proposition of the Jakarta food sector BUMD holding company

\begin{tabular}{|c|c|c|c|}
\hline No & $\begin{array}{l}\text { Type of } \\
\text { Customer }\end{array}$ & $\begin{array}{c}\text { Value } \\
\text { Proposition } \\
\text { Elements }\end{array}$ & Description \\
\hline \multirow[t]{2}{*}{1} & \multirow{2}{*}{$\begin{array}{l}\text { Supply side: } \\
\text { Suppliers, } \\
\text { tenants, } \\
\text { traders }\end{array}$} & $\begin{array}{l}\text { Best } \\
\text { performance }\end{array}$ & $\begin{array}{l}\text { Operations are more efficient because the activities carried out by the } \\
\text { BUMD holding company do not overlap and use shared resources, hence } \\
\text { increases the efficiency. Furthermore, decisions taken can be more } \\
\text { accurate and there will be acceleration and simplification of services and } \\
\text { ease in carrying out business, including licensing }\end{array}$ \\
\hline & & Accessibility & $\begin{array}{l}\text { Planning, consolidation, development and control of facilities and } \\
\text { infrastructure that is faster, safer and more comfortable can be fulfilled, } \\
\text { including the addition of trading places, improvement of facilities for } \\
\text { traders and cleanliness of selling locations. }\end{array}$ \\
\hline \multirow{9}{*}{2} & \multirow{3}{*}{$\begin{array}{l}\text { Demand } \\
\text { side: Upper } \\
\text { class }\end{array}$} & Accessibility & The products or services provided are easily accessible to the upper class \\
\hline & & Comfort & $\begin{array}{l}\text { The benefits of quantitative and qualitative facilities can be provided by } \\
\text { the holding company according to the needs of the upper class }\end{array}$ \\
\hline & & $\begin{array}{l}\text { Availability of } \\
\text { supply }\end{array}$ & $\begin{array}{l}\text { Holding company uses a combination business (control vertically and } \\
\text { horizontally), therefore the diversity of food supply according to the needs } \\
\text { of the upper class can be more guaranteed }\end{array}$ \\
\hline & \multirow{3}{*}{ Middle class } & Accessibility & $\begin{array}{l}\text { The products or services provided are easily accessible to the middle } \\
\text { class }\end{array}$ \\
\hline & & Comfort & $\begin{array}{l}\text { The benefits of quantitative and qualitative facilities can be provided by } \\
\text { the holding company according to the needs of the middle class }\end{array}$ \\
\hline & & $\begin{array}{l}\text { Availability of } \\
\text { supply }\end{array}$ & $\begin{array}{l}\text { The holding company uses a combination business, namely control } \\
\text { vertically and horizontally, therefore the diversity and quantity of food } \\
\text { supply according to the needs of the middle class can be more } \\
\text { guaranteed. }\end{array}$ \\
\hline & \multirow{3}{*}{ Lower class } & Accessibility & The products or services provided are easily accessible to the lower class \\
\hline & & Comfort & $\begin{array}{l}\text { Quantitative and qualitative benefits of facilities can be provided by the } \\
\text { holding company according to the needs of the lower class in accordance } \\
\text { with the assignment of the Jakarta Provincial Government }\end{array}$ \\
\hline & & $\begin{array}{l}\text { Availability of } \\
\text { supply }\end{array}$ & $\begin{array}{l}\text { The holding company uses a combination business, namely control } \\
\text { vertically and horizontally, therefore the diversity and quantity of food } \\
\text { supply according to the needs of the lower classes can be more } \\
\text { guaranteed. }\end{array}$ \\
\hline
\end{tabular}

Channels. The holding company need to evaluate the marketing channels of the three BUMDs. Therefore, the reformation aims to satisfy customers according to segmentation through value creation, efficiency, and effectiveness of the holding companies. Three marketing channels can be evaluated, namely:

- Direct marketing: This is carried out with channels owned by BUMD through resources and employees at the head and branch office. It has the purpose of finding new customers or maintaining existing ones. Also, evaluation is carried out on promotions through exhibitions or events that are independently conducted, which may duplicate or even cancel each other;

- Indirect marketing: This is carried out by BUMD through cooperation with a second or third party;

- The newest way through the use of IT and social media is using Instagram, Facebook, Twitter, Youtube, etc.

Customer Relationship. The evaluation was conducted by reformulating the three BUMDs with existing and potential customers according to the target of the company. 
Meanwhile, there are several options in building customer relationships on the supply side, for example, personal and dedicated assistance, as well as automated service. On the demand side, holding companies need to reformulate how to strengthen public relations for provided services. Also, the relationship patterns that are built need to be specific, for example, stratification in an economic, age, and interactive way. The media used include newsletters, IT, and social media.

The holding company can build collaborative customer data by creating relationships between stakeholders on the supply, demand, and BUMD sides through data. With this, the company management can carefully analyze the relationship between customers from the supply and demand sides in a balanced manner. Therefore, the results of the analysis and decisions are more effective, efficient, and right on target

Key Resources. The main resources of a holding company consist of:

- Physical facilities: movable and immovable assets of the three BUMDs;

- Financial: full capital support from the Provincial Government due to majority share ownership and even all of the food company;

- Human resources: in terms of quantity and quality, the three BUMDs have adequate human resources as a driving force in their operations at all levels in the organizational structure;

- Intellectual: the employees are very experienced in running the business according to their focus. Furthermore, they have experts in the respective fields as well as thousands of experienced employees.

These four main resources can be used as initial capital in consolidating the three BUMDs.

Key Activities. The holding company needs to formulate the key activities of the three BUMDs by synchronizing and synergizing them towards:

- Production activities: these include activities to support the availability of products including raw materials, production, distribution channels. Currently, they tend to carry out production with the same commodities;

- Marketing: the holding company needs to synchronize and focus joint marketing activities on all sectors;

- Customer services: as a bridge between BUMD and customers, this activity is very important as feedback from customers about the provided services. In state enterprises, this section is often the weakest due to management without using customer information as part of decision making;

- IT: with technological advancements that have changed the consumption pattern of all circles in the community, an IT approach is absolutely necessary. Therefore, companies need to consolidate all activities related to the development and use of IT;

- Arrangement of assets: this activity includes the development, management, maintenance, and control of assets.

Key Partnership. Based on the expert's opinion, the two main partners of the holding company are:

- Provincial Government, which include the Department of Food Security, Maritime Affairs and Agriculture (DKPKP), Economic Bureau, Regional Financial Management Agency (BPKD), BP BUMD PM, and Bank DKI Jakarta. Meanwhile, the DKI Provincial Government is the main partner that has the most influence on the direction and objectives of BUMD because it is the absolute or majority owner of the shares. It also issues policies or regulations that are relating to the achievement of certain assignments;

- DPRD, especially Commission C, as a partner of the Jakarta Provincial Government, has its duties and functions in making regional regulations, budgets, and supervision. Furthermore, the duties of the DPRD in collaboration with the Provincial Government include determining the amount of PMD allocated to BUMD.

Benefits. The benefits that a BUMD holding company expects in the food sector are: 
- More efficient operational costs: The holding company will increase the capacity in order to be more efficient in decision-making process, which will have an impact on operating costs;

- Ease of access to capital sources: The holding company will increase the leverage, therefore BUMD can increase their capital;

- The amount of assets and networks of the three BUMDs: the total assets in 2018 were Rp. 5.305 trillion with the number of traditional markets spreading throughout the Jakarta area and an extensive network outside this region;

- PMD support from DKI Jakarta Provincial Government: as the sole owner of the BUMD (except for the Tjipinang Jaya Food Station for 99.98\%), PMD support will be provided by the DKI Provincial Government;

- Increasing services to the community: in addition to seeking profit, the establishment of BUMD also aims as a public service. Hence, the company can accelerate public services due to the resources consolidation and strengths of the three BUMDs.

Obstacles. Some of the obstacles in achieving this strategy are:

- Sub-optimal corporate governance: the opinion of 5 experts places GCG as the highest variable to improve the performance and growth of BUMD;

- Disparities in human resources, capital, and financial conditions: the number of employees of Perumda Pasar is more than PD. Dharma and PT. Tjipinang Jaya Food Station. Meanwhile, for capital and financial conditions, PD. Dharma faces bigger problems than the other 2 BUMDs;

- Political intervention: although the results of the AHP analysis rank 11 out of 12 factors that influence the performance and growth of BUMD, experts admit that political intervention occured in all three BUMDs and affects their operations.

\section{CONCLUSION}

BUMD management, good corporate governance and holding company strategies are the most important and main Actor, Factor and Alternative for improving the performance and growth of BUMD in Jakarta. Also, challenges in the development of holding company in food sector include less optimal GCG, disparities in human resources, capital and financial conditions for each BUMD including political interventions that need to be addressed first by the management. This research object is BUMD in the food sector. Hence, the results cannot be generalized. Also, the influence of several variables may change over time as well as the result itself. Therefore it is suggested that further research can develop a more comprehensive model.

\section{REFERENCES}

1. Asaari F. 2000. Enhancing BUMD performance in DKI Jakarta regional government: An analysis of BUMD privatization and restructuring through the development of holding companies and municipal bonds [thesis]. FISIP. University of Indonesia.

2. Baye and Prince. 2013. Managerial Economics and Business Strategy. (US): Mc. Graw Hill Education.

3. Bhatt PR. 2016. Performance of government linked companies and private owned companies in Malaysia. International Journal of Law and Management 58(2): 150-161.

4. Creswell JW. 2014. Research Design: Qualitative, Quantitative and Mixed Methods Approaches. London (UK): Sage.

5. David FR. 2011. Strategic Management Concept and Cases. Thirteenth edition. New Jersey (US): Pearson Education, Inc.

6. Djohanputro B. 2004. Corporate Restructuring Based on Value Strategy towards Competitive Advantage. Jakarta (ID): PPM publisher.

7. Ferial F, Suhadak, Handayani SR. 2016. The effect of Good Corporate Governance on financial performance and its effect on firm value (study of State-Owned Enterprises 
listed on the Indonesia Stock Exchange 2012-2014 period. Journal of Business Administration. 33(1):146-153.

8. Gilson SC. 2001. Creating Value through Corporate Restructuring. Boston (US): John Wiley \& Sons Inc.

9. Hassard J, Morris J, Sheehan J, Yuxin X. 2010. China's state-owned enterprises: economic reform and organizational restructuring. Journal of Organizational Change Management. 23(5):500 - 516.

10. Holida F, Suryadi H. 2012. The Influence of Good Corporate Governance on the Performance of Regionally Owned Companies. Journal of Democracy and Regional Authonomy. 10:1-66.

11. Johnson G, Kevan Scholes K, Whittington R. 2005. Exploring Corporate Strategy: Text and Cases. Seventh Edition. London (GB): Prentice Hall.

12. Krishnamurti C, Vishwanath S.R. 2008. Mergers, Acquisitions and Corporate Restructuring. California (US): SAGE Publications Inc.

13. Kohli S, Timelin B, Fabius V, Veranen SM. 2020. How COVID-19 is changing consumer behavior -now and forever. McKinsey \& Company.

14. Osterwalder A, Pigneur Y. 2010. Business model generation: a handbook for visionaries, game changers and challengers. Amerika Serikat (US): John Wiley \& Sons, Inc.

15. Pomerleano M, Shaw W (eds). 2005. Corporate restructuring lessons from experience. Washington DC (US): The World Bank.

16. Pranoto T. 2017. BUMN holding company: concept, implementation, and benchmarking. Jakarta (ID): Management Institute, Faculty of Economics and Business, University of Indonesia.

17. Saaty TL. 1993. The Analytical Hierarchy Process: Planning, Priority Setting, Resource Allocation. Pittsburgh (US): University of Pittsburgh Pers.

18. Thompson J, Martin F. 2005. Strategic Management Awareness and Change. 5th Edition. Thompson Learning: ISBN 978-1-84480-083-4.

19. Vance DE. 2009. Corporate Restructuring from Cause Analysis to Execution. New York (US): Springer.

20. Wong SCY. 2004. Improving corporate governance in SOEs: an integrated approach. Corporate Governance International J. 7(2):1-15.

21. World Bank. 2020. Global Economic Prospects, June 2020. Washington, DC: World Bank. DOI: 10.1596/978-1-4648-1553-9. License: Creative Commons Attribution CC BY 3.0 IGO. 